\title{
Be wary of passive resistance to health information systems
}

\section{Heru Santoso Wahito Nugroho}

Health Polytechnic of Ministry of Health in Surabaya, Indonesia Pucang Jajar Tengah Street 56 Surabaya, Indonesia, 60282 heruswn@gmail.com (corresponding author)

\section{Setya Haksama}

Faculty of Public Health, Airlangga University, Indonesia setyahaksama@fkm.unair.ac.id

\section{Bambang Hadi Sugito}

Health Polytechnic of Ministry of Health in Surabaya, Indonesia bambanghadi_sugito@yahoo.com

\section{Ristya Widi Endah Yani}

Faculty of Dentistry, University of Jember, Indonesia ristya_widi@unej.ac.id

\section{Suparji}

Health Polytechnic of Ministry of Health in Surabaya, Indonesia suparjiyozabri@gmail.com

\section{Hadi Prayitno}

Faculty of Social Science and Polytical Science, University of Jember, Indonesia hprayitno29@yahoo.co.id

\section{Handoyo}

Health Polytechnic of Ministry of Health in Surabaya, Surabaya, Indonesia handoyo0801@gmail.com 


\section{ABSTRACT}

Implementation of health information systems (HIS) has resulted in multiple duties for health professionals as health care workers and HIS operators. This dual task can lead to increased effort for them, which can lead to resistance to HIS, either actively or passively. Both must be handled seriously because it often leads to the failure of HIS implementation. Meanwhile, passive resistance must be cautioned because in the early stages it is usually unknown to managers that it fails to be anticipated and worsens. As a strategic solution, organizations must always maintain and improve organizational support for users.

Keywords: Health information systems, passive resistance, organizational support.

\section{INTRODUCTION}

In the current global era, the use of information and communication technology (ICT) in the implementation of health information systems (HIS) has been widely used ${ }^{1}$, with health professionals as users. Most of HIS is a mandatory information system, which requires users to run the system unconditionally. There is no option for them to use or not to use the system ${ }^{2}$.

Thus, in addition to performing the duties of health professionals, they must also perform the additional task of operating HIS. With this dual task, they often complain that their workload is growing. Not all health professionals are tolerant of this dual assignment. The fact shows that there are still many health professionals who are not yet familiar with ICT. For those who are classified as stuttering ICT, it may be necessary to improve efforts so that they can run HIS well. Additional efforts to be performed by the user in order to operate the ICT are commonly known as "increased effort" ${ }^{3,4}$.

"Increased efforts" can be attributed to various factors, such as low levels of education, lack of training experience on ICT and change in job content ${ }^{3}$. Related to "change in job content" , or "change in profession content", the implementation HIS will lead to significant 
changes to the job description that must be performed. They are required to be proficient in operating ICT devices.

The above conditions can lead to resistance to HIS that have been imposed. This problem can have a serious impact on the sustainability of HIS, since end users as part of the brainware component are a central component of an information system in addition to hardware and software ${ }^{7}$. Some researchers have stated emphatically that failure to initiate a change occurs as a result of resistance to the change $\mathrm{e}^{7,8,9,10}$.

User resistance is defined as "opposition of a user to change associated with a new information systems implementation" the perspective of interaction theory, resistance to information systems is caused by the interaction between people with the system ${ }^{5}$. According to the theory of interaction, neither the system nor the characteristics of society are the cause of resistance to change. This theory explains that the 'real reason' of resistance to change is the perceived value of users and social content obtained or lost before or after the implementation of information systems ${ }^{13}$.

Resistance to information systems can occur in various forms, ranging from closed or not shown openly to openly demonstrated, even attempts to block or interfere with the smooth implementation of the system. Generally, resistance to information systems can be divided into two major classes of active resistance and passive resistance ${ }^{14}$. Active resistance is characterized by behaviors that openly indicate resistance to change, ranging from less aggressive rejection to highly aggressive rejection. On the other hand, passive resistance is not accompanied by overt refusal ${ }^{15}$.

But whatever the form, user resistance will be a threat to the sustainability of the implementation of HIS, so that should be done various studies that can produce problem solving for the existence of resistance. 


\section{BE WARY OF PASSIVE RESISTANCE TO HIS}

Why passive resistance to the implementation of HIS should be wary of? Before answering the questions above, we need to look at the theory of user acceptance of the implementation of information systems. Technology acceptance model (TAM) as the most popular "user acceptance model of ICT" explains that user acceptance is evidenced by "actual system use" or user action to operate $\mathrm{ICT}^{16}$. So referring to this theory, if health professionals are already running the HIS, then they are considered to have accepted the system.

But resistance theory looks at the case differently ${ }^{4}$. If a health professional has not run the HIS, it may be true that he or she is considered resistant to the system. But if someone has run the HIS, can not the person is automatically considered not resistant to the system. They may run the system not based on awareness to run it for the sake of organizational development, but simply to free themselves from obligations or to avoid punishment for violations of organizational rules.

In the previous section it has been stated that in general, HIS are mandatory, so health professionals are bound by the obligation to operate the system. Often managers do not know or pay attention to whether these end-users are willing to accept this dual task voluntarily. For example, in one of the district health offices in Indonesia, when the Maternal and Child Health Information System is in place, all the midwives in the district have operated the system well. These conditions indicate that they do not have problems in terms of knowledge or skills. But a few years later, one by one end-user no longer runs the system. The results of in-depth interviews indicate that they complain that their tasks are heavier as a result of dual duties as health workers and as users of HIS ${ }^{17}$.

The examples show that in the early stages, some of the end-users may already be resistant to HIS, but they still survive to run the system, due to mandatory enforcement rules accompanied by strict supervision systems. This rigorous supervision makes end-users feel 
strong pressure from the organization against them to run the HIS. When supervision becomes loose as in the case of a change of leadership team, or the change of HIS managers, end-users will feel free from the pressure, so that little by little they will abandon their obligations as users of HIS. Resistance may be initiated by negative actions at a mild level such as working slowly or procrastinating data entry ${ }^{12,14,18}$. These are some examples of signs of passive resistance.

Passive resistance can also be seen from the low passion, enjoyment and adaptability in running the information system ${ }^{19}$. There are six main characteristics of passive resistance: 1 ) agreeing verbally but not following through, 2) failing to implement change, 3) procrastinating / dragging feet, 4) feigning ignorance, 5) withholding information, suggestions, help or support, 6) standing by and allowing the change to fail ${ }^{14}$.

\section{STRATEGIC SOLUTION}

Based on the above description it can be clearly known that passive resistance tends to be hidden and when there is opportunity, then the resistance begins to look and eventually grow to be more severe. At a time when resistance is still hidden, often the management does not know it, so there is no anticipatory action to prevent it from progressing to a more severe condition. One important way to anticipate passive resistance is to improve or maintain organizational support for users in the implementation of HIS. This support can be realized in the form of: 1) supervisor support such as support from supervisors and managers of information systems, 2) supporting working conditions such as mentoring services, technical assistance, communication between users with direct supervisor, good communication between users with system managers and the provision of adequate facilities, and 3) rewards, both financially and non financially such as self-esteem, sense of achievement, sense of development $^{17,20}$.

\section{REFERENCES}


1. Nugroho, H.S.W., Supriyanto, S. and Notobroto, H.B., Indicators of behavioral intention to implement maternal and child health information systems. Dama International Journal of Researchers, 2016, 1(6), 68-71.

2. Gewald, H. and Gewald, C., Physician's use of mandatory information systems: an exploratory research in German hospitals. In Proceedings of The 50th Hawaii International Conference on System Sciences, Big Island, Hawaii, 2017, pp. 3411-3420.

3. Salih, S.H., Hussin, A.R.C. and H.M. Dahlan, User resistance factors in post ERP implementation. Journal of Research and Innovation in Information Systems, 2013, 3, 19 27.

4. Nugroho, H.S.W., Polnok, S., Martiningsih, W. and Devassy, D., Increased effort and user's expectation as determinants of resistance due to a change in the implementation of educational information system of health worker. Dama International Journal of Researchers, 2017, 2(2), 100-106.

5. Jiang, J.J., Muhanna, W.A. and Klein, G. "User resistance and strategies for promoting acceptance across system types. Information \& Management, 2000, 37(1), 25-36.

6. Alfian, How leadership style impact the management information system quality-a theorytical study. International Journal of Scientific \& Technology Research, 2016, 5(6), 11-15.

7. Lawrence, P.R., How to deal with resistance to change. Harvard Business Review, 1969, 49-57.

8. Maurer, R., Using resistance to build support for change. The Journal for Quality and Participation, 1996, 19(3), 56.

9. Strebel, P., Choosing the right change path. California Management Review, 1994, 36(2), 29-51.

10. Waddell, D. and Sohal, A.S., Resistance: a constructive tool for change management. Management Decision, 1998, 36(8), 543-548.

11. Kim, H.W. and Kankanhalli, A., Investigating user resistance to information systems implementation: a status quo bias perspective. MIS Quarterly, 2009, 33(3), 567-582.

12. Klaus, T.P., An examination of user resistance in mandatory adoption of enterprise systems. Graduate Theses and Dissertations, University of South Florida, 2005.

13. Kendall, K.E., The significance of information systems research on emerging technologies: seven information technologies that promise to improve managerial effectiveness. Decision Sciences, 1997, 28(4), 775-792.

14. Hultman, K., Managing resistance to change. In Encyclopedia of Information Systems (vol. 3), Academic Press, San Diego CA, 2003, pp. 693-705.

15. Ackah, D., Alvarado, A.E., Nugroho, H.S.W., Polnok, S. and Martiningsih, W., Understanding the resistance to health information systems. Health Notions, 2017, 1(1), 45-50.

16. Davis, F.D., Bagozzi, R.P. and Warshaw, P.R., User acceptance of computer technology: a comparison of two theoretical models. Management Science, 1989, 35(8), 982-1003.

17. Nugroho, H.S.W., Peran perceived organizational support, personal characteristic, dan perceived enjoyment dalam model penerimaan sistem informasi kesehatan ibu dan anak. Dissertations, Faculty of Public Health, Airlangga University, Surabaya, 2016.

18. Klaus, T. and Blanton, J.E., User resistance determinants and the psychological contract in enterprise system implementation. Europan Journal of Information Systems, 2010, 19(6), 625-636.

19. Nugroho, H.S.W., Supriyanto, S. and Notobroto, H.B., User enjoyment in health information systems implementation. Global Scholastic Research Journal of Multidisciplinary, 2016, 2(2), 15-23. 
20. Nugroho, H.S.W., Supriyanto, S. and Notobroto, H.B., Indicators of organizational support in implementing maternal and child health information system. International Journal of Public Health Science, 2016, 5(3), 280-283. 